\title{
The wTo entry \\ of China and its impact on the countries of the Caribbean Basin
}

\section{Eduardo Gitli \\ egitli@racsa.co.cr \\ Randall Arce \\ marce@racsa.co.cr \\ International Centre \\ of Economic Policy \\ for Sustainable \\ Development (CINPE), \\ Costa Rica}

The entry of China into the World Trade Organization, if it takes place, will unquestionably have a major impact on many nations. What is focused on here is the impact it would have on trade between the United States and the countries of the Caribbean Basin. The problems caused to the latter by Mexican membership of the North American Free Trade Agreement could be exacerbated by the shift of forces that would result from this new situation. The major expansion of textile and clothing exports from China to the United States that is in prospect would intensify the competition faced by the countries of the Basin and Mexico in that market. Nonetheless, the recent expansion of the trade benefits granted by the United States to the Caribbean Basin, which came into effect on 1 October 2000, gives a short respite (five years or so) in which these countries can seek to consolidate their exports, particularly of wearing apparel. In the case of footwear, increased trade between China and the United States could have adverse effects on the exports of the Dominican Republic to the United States market. As regards medical instruments, Chinese exports would compete strongly with those of Costa Rica and the Dominican Republic in that same market. 


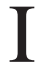

\section{Introduction}

The People's Republic of China ${ }^{1}$ has become an important player in the world economy. After making great changes to its productive and organizational structure, the country has succeeded in sustaining high growth rates over recent years, and as a result has positioned itself as one of the world's leading exporters and importers as well. Its performance has been heavily conditioned, however, by the fact that it is not a member of the World Trade Organization (WTO), something that has limited its scope for trade expansion.

For this reason China is seeking to join wTO, half a century after it left that body's predecessor organization, the General Agreement on Tariffs and Trade (GATT). Its

\section{II}

\section{Background}

China was one of the 23 countries that originally signed GATT in 1948. After the 1949 revolution, however, the Government of Taiwan announced that China would no longer form part of GATT. In 1986, China notified GATT of its desire to regain its status as a contracting party and its intention to do so. In March 1987, a working group was formed to analyse the status of China, the first meeting being held in October that same year (WTO, 2000).

China has about 1.3 billion inhabitants and has grown quickly in recent years. On average, its gross domestic product (GDP) grew by over $11 \%$ annually in 1990-1997, making it one of the fastest growing countries in recent years. Average inflation over the period was less than 8\%, and in 1998 and 1999 prices actually fell by $0.8 \%$ and $1.4 \%$, respectively (World Bank, 1999 and IMF, 2000b). As of about 1996, 71.2\% of the country's gross industrial product was generated by private-sector companies, ${ }^{2}$ and these accounted for

\footnotetext{
1 This paper deals with the People's Republic of China, but for brevity's sake we shall refer to that country simply as China.

${ }^{2}$ This percentage should be interpreted with caution, as it includes some township enterprises as well as unequivocally private ones.
}

objective is to improve its trading position in the international economy, in order to take advantage of the gains offered by globalization. The bilateral agreement signed between China and the United States in November 1999 gave a considerable boost to the negotiations being conducted by China with a view to entering the organization that has replaced GATT.

The scope of this bilateral agreement as regards trade between the United States and China has yet to be seen. Nonetheless, consideration has to be given to the effects that it might have on trade between the Caribbean Basin countries and the United States. That is the primary objective of this article.
42.6\% of urban employment (Lin, Cai and $\mathrm{Li}, 1998$, p. 422).

Although per capita income in China is low, the country's total gross national product (GNP) in purchasing power parity terms is four times Brazil's and more than twice Germany's. Consequently, it is a strong potential customer for food, capital goods and basic electrical household appliances. Production for export in the country is largely confined to a small area of territory. Approximately $70 \%$ of the foreign direct investment (FDI) it receives goes to five coastal provinces situated in the east and south-east of the country: Guangdong, Jiangsu, Fujian, Shanghai and Shandong. ${ }^{3}$ These provinces are regarded as a very important part of the "Chinese miracle", as they grew at rates of over 20\% between 1985 and 1989 (Mody and Wang, 1997, p. 294). This is partly due to the location there of special economic zones (SEZs), but also reflects the geographical concentration of the

\footnotetext{
${ }^{3}$ For the purposes of this study, investment from Hong Kong Special Administrative Region and Taiwan Province of China, henceforth referred to as Hong Kong and Taiwan, has been classified as foreign investment.
} 
organizations that the Chinese authorities have allowed to trade (USITC, 1999b, pp. 2-23). Companies situated in these zones receive substantial incentives, such as exemption from profit taxes and the payment of tariffs on capital goods or raw materials imported for reprocessing there. These zones are major recipients of low-processing operations from Hong Kong and Taiwan, especially for garment products (Bosworth and Ofer, 1995).

The importance of FDI in the Chinese economy is considerable. In $1998,51.8 \%$ of all FDI in the countries of Asia and the Pacific went to China (UNCTAD, 1999). ${ }^{4}$ Within China, FDI is heavily concentrated by origin. In 1997, almost half of all new FDI came from Hong Kong (table 1), with Japan (9.6\%), Taiwan (7.3\%), the United States $(7.2 \%)$ and Singapore $(5.8 \%)$ making more modest contributions. This concentration of FDI may be due to the restrictions that China places on capital inflows, which do not apply to Hong Kong; this could mean that some of this capital is really Taiwanese. Of the FDI received, $62 \%$ goes into manufacturing (USITC, 1999b, pp. 2-14).

Where export destinations are concerned, China's largest trading partners are Hong Kong (22.7\%), Japan (20.2\%) and the United States (18.2\%) (IMF, 2000a). Labour-intensive manufactures, such as wearing apparel, footwear, toys, games, sports equipment and leather products are among the country's main export items. This reflects the fact that, in comparison with other countries, China is labour-rich and capital-poor.

As regards the country's suppliers, the largest are Hong Kong (34.8\%), Japan (12.8\%), Taiwan (9.8\%),
TABLE 1

China: Accumulated foreign direct investment, by country of origin, 1997

(Millions of dollars and percentages)

\begin{tabular}{lrc}
\hline Country of origin & Value & Percentage \\
\hline Hong Kong & 20630 & 45.6 \\
Japan & 4330 & 9.6 \\
Taiwan & 3290 & 7.3 \\
United States & 3240 & 7.2 \\
Singapore & 2610 & 5.8 \\
Republic of Korea & 2140 & 4.7 \\
United Kingdom & 1860 & 4.1 \\
Germany & 990 & 2.2 \\
Macao & 390 & 0.9 \\
Canada & 340 & 0.8 \\
Australia & 310 & 0.7 \\
Subtotal & 40130 & 88.6 \\
Others & 5148 & 11.4 \\
Total & 45278 & 100.0 \\
\hline
\end{tabular}

Source: USITC (1999b).

the United States (7.4\%) and the Republic of Korea $(7.1 \%)$. The main import products are aircraft, electrical machinery, fertilizers and non-electrical machinery (IMF, 2000a). ${ }^{5}$

The composition of China's trade has changed greatly over the last 20 years, shifting from a primary product-based structure to a manufactures-based one. In $1997,85 \%$ of Chinese exports were manufactured goods. ${ }^{6}$

\section{III}

\section{The negotiating process for China's wTO entry}

China is one of 30 countries currently negotiating entry into WTO (formerly GATT). The country is carrying out major reforms and turning its economy into a more market-based one. The admission process is being negotiated by a working group composed of WTO members. Initially (from 1987), the working group attached to GATT analysed the Chinese visible trade

\footnotetext{
4 These data do not include investment in Japan. If we include Hong Kong, which has been a region with special status within China since 1997, the figure rises to $53.7 \%$.
}

regime. But from 1995 onward, the group attached to the newly created WTO included trade in services, the new rules on non-tariff measures and the rules on intellectual property rights among the subjects for analysis.

A very important part of China's wTO admission process are the bilateral negotiations being carried out

\footnotetext{
5 Some Hong Kong imports and exports are actually redirected, so this structure may not be altogether accurate.

${ }^{6}$ Authors' estimate arrived at using the PC-TAS world trade database.
} 
between that country and interested members of the organization. These member countries are proceeding bilaterally to negotiate the prerequisites for entry. At the end of the process, China has to secure two thirds of member countries' votes to be allowed into the organization. ${ }^{7}$ The working group is responsible for overseeing the general progress of these bilateral discussions. ${ }^{8}$

Figure 1 shows what stages China still has to go through before it can enter wTO. Firstly, it has to finish negotiating with the countries that have requested this, a stage that has involved difficulties with the European Union. After that, it will have to consolidate all its negotiations within the working group and each member country will have to decide whether it approves of China entering WTO. Then the General Council (made up of all the member countries of the organization) will have to pass or reject in its entirety a set of deadlines and conditions for Chinese entry. The Council generally takes these decisions by consensus, but if this is not possible membership can be approved by a two-thirds majority. Lastly, China has to begin complying with its obligations, and becomes a member of WTO (GAO, 2000, p. 9).

\footnotetext{
${ }^{7}$ Although negotiations are bilateral at this stage, when China enters WTO it will have to extend any bilateral concessions automatically to all the other countries by virtue of the most favoured nation principle.
}

\section{Unilateral opening by China}

In 1998, China reported on some of the concessions it had granted during the 12 years since it had submitted its formal application for readmission to GATT (now WTO). Some of them (wTO, 2000) are as follows:

- China reduced its average tariff (other than for agricultural products) from $42.7 \%$ in 1992 to $17 \%$ in 1998 , and planned to reduce them further, to $10 \%$ by 2005 .

- It reduced the number of non-tariff measures from 1,247 in 1992 to less than 400 in 1998. There is a timetable for abolishing measures inconsistent with WTO provisions.

- It agreed to sign the Information Technology Agreement, which provides for tariffs on a variety of products in this category to be reduced to zero.

- It asserted that it did not operate any subsidy systems for agricultural exports.

- It maintained that it had progressed with negotiations on trade in services. At that time, there were 150 foreign banks operating in China.

\footnotetext{
${ }^{8}$ By July 2000, China had concluded negotiations with 35 member countries. Agreement with the European Union had been delayed owing to disagreements over the opening up of service-related sectors in China, such as telecommunications, financial services and insurance.
}

THE WTO ENTRY OF CHINA AND ITS IMPACT ON THE COUNTRIES OF THE CARIBBEAN BASIN • EDUARDO GITLI AND RANDALL ARCE 
FIGURE 1

\section{China: Stages remaining in the World Trade Organization} (wTo) entry process
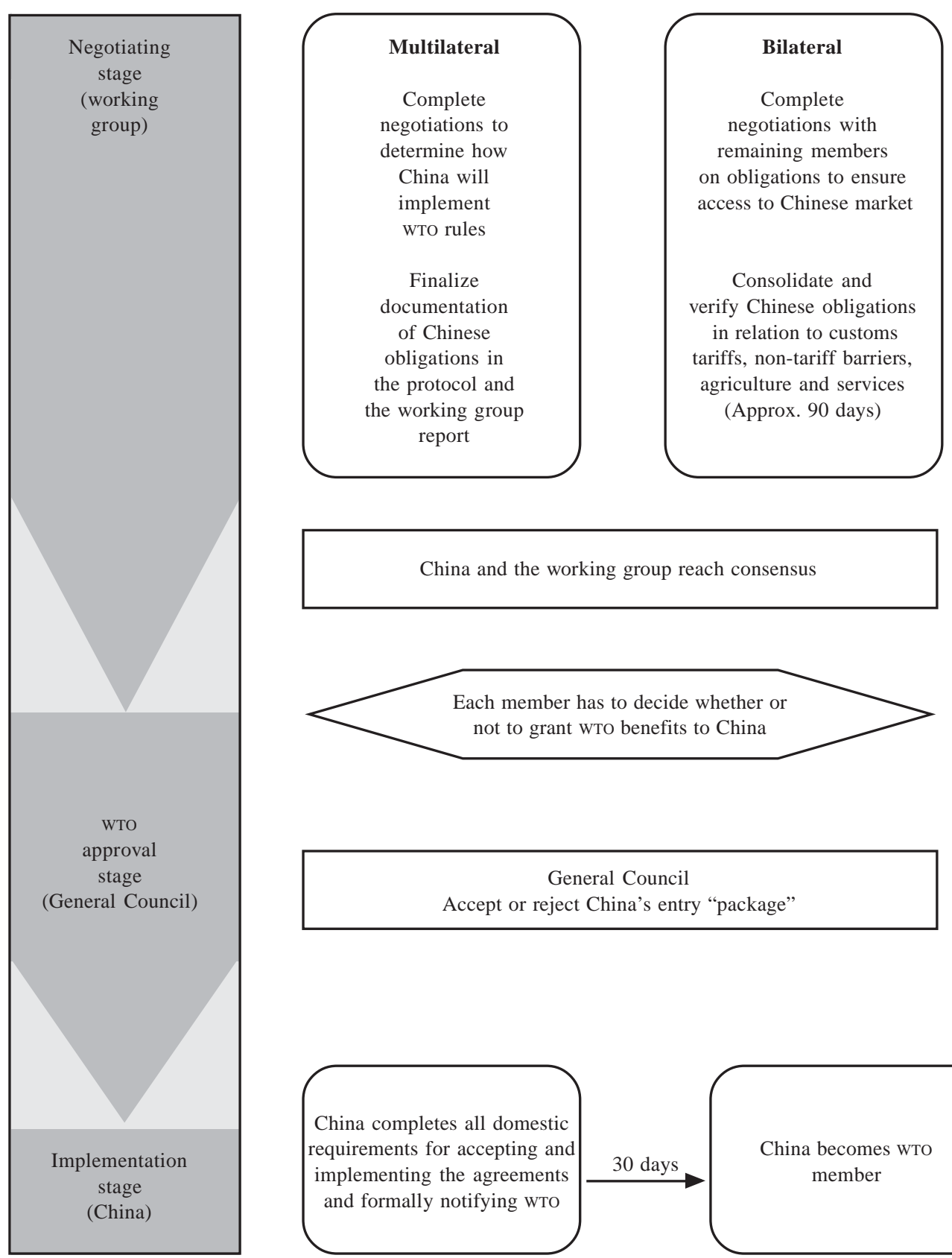

China completes all domestic requirements for accepting and implementing the agreements and formally notifying WTO

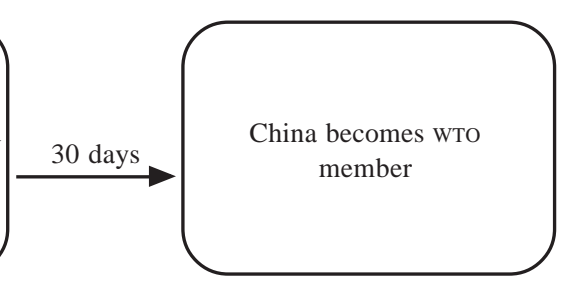

Source: GAO (2000). 


\section{IV}

\section{Relations between China and the United States}

\section{Trade between the two countries}

China is an important bilateral trading partner for the United States, with $7.2 \%$ of United States imports coming from China in 1997, a considerable increase on the $5.4 \%$ recorded in 1993 (table 2). As regards United States exports, sales to China remained stable from 1993 to 1997, accounting for about $1.9 \%$ of the total. This figure shows that the United States can aim to increase its shipments to the country substantially. China ranks fourth among countries of origin for United States imports and thirteenth among recipients of United States exports.

Seen from the Chinese side, the United States is a very important trading partner, taking $25.9 \%$ of its exports in 1997 and supplying $15.1 \%$ of imports. The situation was a very favourable one for China, as its balance of trade was in surplus by US $\$ 49.747$ billion.

Table 3 shows the structure of trade between the United States and China in 1998. As can be seen, United States imports fell mainly into four sections: machinery and appliances, electrical equipment and parts (29\%), miscellaneous manufactured articles $(21.4 \%)$, footwear, headgear and artificial flowers $(13.1 \%)$ and textiles and textile articles $(10.1 \%)$. United States exports to China, meanwhile, centred on three sections: machinery and appliances, electrical equipment and parts $(31.9 \%)$, transportation equipment $(26.6 \%)$ and products of the chemical or allied industries $(11.5 \%)$.

TABLE 2

United States and China: Importance

of bilateral trade

(Percentages)

\begin{tabular}{lcc}
\hline & 1993 & 1997 \\
\hline $\begin{array}{l}\text { United States imports from China as } \\
\text { percentage of all United States imports }\end{array}$ & 5.4 & 7.2 \\
$\begin{array}{l}\text { United States exports to China as } \\
\text { percentage of all United States exports }\end{array}$ & 1.9 & 1.9 \\
$\begin{array}{l}\text { Chinese imports from United States as } \\
\text { percentage of all Chinese imports }\end{array}$ & 13.0 & 15.1 \\
$\begin{array}{l}\text { Chinese exports to United States as } \\
\text { percentage of all Chinese exports }\end{array}$ & 22.4 & 25.9 \\
\hline
\end{tabular}

Source: United States Department of Commerce, Module for the analysis of growth in international commerce (MAGIC), and United Nations (PC-TAS).

\section{The China-United States Agreement ${ }^{9}$}

On 15 November 1999, the United States and China signed a bilateral agreement that prepared the ground for China to enter WTO. This agreement covered subjects such as access for United States products to the Chinese market, opportunities for investing in services, trade and distribution rights, among other things.

This agreement is not a one-off. Rather, it forms part of a general shift in the way the United States relates to China, owing in part to the importance that the latter has taken on in recent years. After the tragic events of Tiananmen Square, relations between the two countries were subdued for over a decade. In 1996, however, President Clinton announced that the stabilization of relations with China would be a priority in his second term, and in 1997 the first summit between the presidents of the two countries sent out a strong signal of normalization.

The main items included in this bilateral agreement are as follows.

\section{a) General provisions}

The agreement includes a number of provisions which in practice mean that China's WTO entry will be subject to unilateral defensive measures devised by the United States in a number of areas. Firstly, it includes a special safeguard mechanism that will remain in force for 12 years after entry. This mechanism can be used to control rapid increases in imports from China that cause or threaten to cause problems in the United States.

\section{b) Antidumping methodology}

The United States can continue to apply a methodology for non-market economies in antidumping cases that concern imports from China. This provision, which will remain in force for 15 years after China enters WTO, will allow the United States to take the special characteristics of the Chinese economy into consideration when it identifies and quantifies possible

\footnotetext{
${ }^{9}$ The description of the main features of the China-United States Agreement is based on United States-China Business Council (2000).
} 
TABLE 3

United States and China: Reciprocal trade structure by Harmonized System sections, 1998 ${ }^{a}$

(Billions of dollars and percentages)

\begin{tabular}{|c|c|c|c|c|c|}
\hline & & Imports & Percentage & Exports & Percentage \\
\hline XVI. & $\begin{array}{l}\text { Machinery and mechanical appliances, electrical equipment } \\
\text { and parts thereof }\end{array}$ & 20385.0 & 29.0 & 4472.8 & 31.9 \\
\hline $\mathrm{XX}$ & Miscellaneous manufactured articles & 15041.3 & 21.4 & 101.3 & 0.7 \\
\hline XII. & Footwear, headgear, artificial flowers & 9230.4 & 13.1 & 33.2 & 0.2 \\
\hline XI. & Textiles and textile articles & 7114.9 & 10.1 & 267.4 & 1.9 \\
\hline XV. & Base metals and articles of base metal & 3052.6 & 4.3 & 469.0 & 3.3 \\
\hline XVIII. & Optical, photographic and musical instruments and apparatus & 2991.7 & 4.3 & 682.2 & 4.9 \\
\hline VIII. & Raw hides and skins, handbags, etc. & 2972.4 & 4.2 & 166.6 & 1.2 \\
\hline VII. & Plastics and articles thereof, rubber and articles thereof & 2388.2 & 3.4 & 445.0 & 3.2 \\
\hline VI. & Products of the chemical or allied industries & 1453.9 & 2.1 & 1613.6 & 11.5 \\
\hline XIII. & Articles of stone, plaster, cement, ceramics, glass & 1276.1 & 1.8 & 90.6 & 0.6 \\
\hline \multicolumn{2}{|l|}{ Subtotal } & 65906.5 & 93.7 & 8341.7 & 59.4 \\
\hline \multicolumn{2}{|l|}{ Others } & 4473.4 & 6.30 & 5692.2 & 40.6 \\
\hline \multicolumn{2}{|l|}{ Total } & 70379.9 & 100 & 14.034 .3 & 100.0 \\
\hline
\end{tabular}

Source: The authors, on the basis of data from the United States Department of Commerce, MAGIC.

a The Harmonized System is divided into 21 sections.

benefits deriving from subsidies. At the same time, China can ask the United States to review specific sectors, or the Chinese economy as a whole, to determine whether they are market-oriented and thus not entirely subject to the special methodology applicable to non-market economies.

\section{c) Trade and distribution rights}

United States companies operating in China will be able to distribute imported products as well as products that they themselves have produced in that country, which should give them a great opportunity to expand exports to China. Formerly, companies could distribute their products only when they produced them directly in China, whereas if they imported them distribution had to be carried out through State enterprises created for that purpose. One of the reasons why United States companies decided to set up production plants in China was to be able to sell into such an important market. Under the terms of the agreement, United States companies will be able to sell their products regardless of where they are produced, which will enable them to increase exports.

\section{d) Services}

The agreement establishes that China will provide access to its communications sector and to those of insurance, financial services, professional services and computer-related services. In telecommunications, once China is a member of wTO, foreign operators will be able to own up to $25 \%$ of mobile telecommunications companies, and this percentage will rise to $49 \%$ from the third year. In Internet services, foreign companies will be able to own up to $30 \%$ of operators in the provinces of Beijing, Shanghai and Guangzhou, and this will rise to $50 \%$ after two years, when all geographical restrictions will have disappeared. Although it is true that China has opened up financial services to some extent, participation in this activity by foreign private-sector companies is still very low. At the same time, the strong growth seen in China's capital markets in the 1990s has become a major incentive for the United States Government to seek to secure access to these markets (United Nations, 1999).

\section{e) Industrial products}

Chinese industrial tariffs are supposed to fall from an overall average of $24.6 \%$ ad valorem in 1997 (higher than actually applied now) to a general average of $9.4 \%$ in 2005. Tariffs on industrial products of particular interest to the United States are to fall to an average of $7.1 \%$ ad valorem, and most of these tariff reductions will be in effect by 2003. Tariffs on automobiles will fall rapidly from today's $80-100 \%$ levels ad valorem to 
$25 \%$ in 2006, with the largest fall taking place the first year after China enters wTO. China agreed to reduce these tariffs in return for a slightly longer grace period. ${ }^{10}$ It also agreed to do away with all tariffs on goods such as computers, telecommunications equipment, semiconductors and other high-technology products in accordance with the Information Technology Agreement, to which China is a signatory. Tariffs for products of this type will fall from the current average of $13.3 \%$ to zero by 2005 .

For wood and paper, tariffs will be cut from their current levels of $12-18 \%$ for wood and $15-25 \%$ for paper to levels that will generally range from $5 \%$ to $7.5 \%$. In the case of textiles, the agreement includes a protocol based on the textile agreements of 1997, under which United States companies and workers can respond to rising textile and garment imports by invoking a safeguard. This safeguard will remain applicable until 31 December 2008, i.e., four years after the wTO Agreement on Textiles and Clothing ceases to operate (White House, 2000).

\section{f) Agricultural products}

China agreed to allow private trade in agricultural products. Chinese tariffs on priority United States products will be reduced from an overall average of $31 \%$ ad valorem to $14 \%$ by January 2004 at the latest. Furthermore, the average Chinese tariff on agricultural products will be reduced from $22 \%$ to $17.5 \%$. The tariff conditions set in the agreement for certain specific sectors of interest to the United States are listed in table 4.

China also agreed to abolish export subsidies, which were a key concern for United States producers of rice and cotton. Other commitments included doing away with sanitary and phytosanitary barriers not based on scientific evidence and granting the right to import and distribute products in China without the need to go through State trading bodies. ${ }^{11}$

\footnotetext{
${ }^{10}$ There are complaints in the United States, however, that the tariff level agreed upon may still be too high and continue to restrict the United States export sector (The Journal of Commerce, 2000a).

${ }^{11}$ While the United States is asking the European Union, wто and China to abolish agricultural subsidies, the country's domestic subsidies to agriculture in the last two years were US\$ 6 billion and US\$ 9 billion, respectively (The Journal of Commerce, 2000c).
}

TABLE 4

China: Tariffs negotiated with the United States

\begin{tabular}{lcc}
\hline $\begin{array}{l}\text { United States } \\
\text { priority products }\end{array}$ & $\begin{array}{c}\text { Current } \\
\text { tariff }(\%)\end{array}$ & $\begin{array}{c}\text { Agreement } \\
\text { tariff }(\%)\end{array}$ \\
\hline Grapes & 40 & 13 \\
Beef & 45 & 12 \\
Chicken and turkey & 20 & 10 \\
Fish & 25.3 & 10.6 \\
Cheese & 50 & 12 \\
Yoghurt & 50 & 10 \\
Ice cream & 45 & 19 \\
Pork & 20 & 12 \\
Wine & 65 & 12 \\
Chicken & 20 & 10 \\
\hline
\end{tabular}

Source: United States-China Business Council (2000).

\section{The position in the United States as regards China's wTO entry}

Labour unions in the United States opposed the agreement signed with China, insisting that the country should improve its labour practices before it was allowed to enjoy normal trade relations. They also argued that the low prices of Chinese products would result in the United States market being swamped by them, leading to job losses (The Journal of Commerce, 2000c).

The subject of respect for human rights in China was also a source of confrontation. Some believed that the United States should not sign an agreement with China until the situation of human rights in that country had improved and they had ceased to be constantly violated (Public Citizen, 1999). Others maintained that significant progress had been made and that it needed to be understood that changes in this area took place only gradually, so that the issue should not act as an impediment to the normalization of relations between the United States and China (Bates, 1999). These considerations seem to have been taken into account, as the legislation that was ultimately passed provides for the creation of a commission to monitor human rights conditions in China and inform Congress of the results.

The issue of the environment does not seem to have been a priority in the agreement. Some believe that the environmental problems that have arisen in China because of the economic boom of recent years threaten the country's fragile social and political structure, and its economic infrastructure. They have demanded that the United States take advantage of this opportunity to cooperate with China on this vital issue (Economy, 1999). On 19 May 2000, the two nations signed a joint 
Box 1

What is meant by Permanent Normal Trade Relations?

Most favoured nation (MFN) trading status is what current United States legislation terms Permanent Normal Trade Relations (PNTR). The status of MFN is the instrument whereby all members of the World Trade Organization (WTO) guarantee to apply permanent normal tariff conditions to one another, so that if China becomes part of wTo it will have to be granted this by the member countries.

The United States will have to pass PNTR legislation for China, as the law at present, in the form of Title IV of the 1974 Trade Act, prevents this status from being granted to the country, as a result of which tariff conditions for Chinese goods currently have to be renewed each year. If this new status were not granted to China, the United States would not benefit from the most important concessions that China has made to become a wTO member, such as liberalization of financial services, telecommunications and distribution. As a result, it is important for the United States Government that the establishment of permanent normal trade relations with China be approved.

Source: Lardy (2000).

environmental cooperation declaration, which stresses issues relating to climate change, the use and transfer of clean technologies and the need to reduce greenhouse gas emissions. This declaration was issued in the framework of the Environment and Development Forum, which is a process of discussions that have been held between the United States and China since 1997. No concrete action has yet been taken, however, to turn United States cooperation with China in this area into a reality.

Apart from commercial considerations, the agreement has considerable geopolitical importance for the United States. The transformation of a poor, closed society (open only in small areas such as the SEZs) into a consumer market of 1.3 billion inhabitants makes economic sense, but it also makes strategic sense to ease the permanent dilemma of economic partnership and political and military confrontation between China and Taiwan, or between China and India or Russia. For this reason, six former Secretaries of State -from Alexander Haig, Henry Kissinger and James Baker to Warren Christopher- issued an open letter of support for Clinton. ${ }^{12}$

\section{V}

\section{Possible effects on the Caribbean Basin}

China's entry into WTO and the recent bilateral agreement signed with the United States could have adverse effects on the development of trade between the Caribbean Basin countries and the United States, owing to increased Chinese competition in certain specific sectors. ${ }^{13}$

\footnotetext{
${ }^{12}$ During the passage of this legislation, the United States Congress debated two closely related subjects: i) the agreement between the United States and China whereby the latter complied with one of its WTO entry obligations, and ii) the passing of legislation on normal trade relations with China, after which there would be no need for annual renewal of the tariffs on imported Chinese goods. In September 2000 this legislation was on the point of being passed, and this was only prevented because some lawmakers demanded the inclusion of conditions relating to greater respect for human rights and to the arms trade.
}

As table 5 shows, there are four sectors in particular whose importance in Chinese exports to the United States could increase competition with Caribbean Basin products: i) wearing apparel, ii) footwear, iii) machinery and appliances, electrical equipment and parts, and iv) optical, photographic and musical instruments and apparatus. While wearing apparel is produced in all the Central American countries and the Dominican Republic, the footwear sector is important only in the latter country, where in 1999 it accounted for $6.6 \%$ of all exports to the United States, whereas for the other

\footnotetext{
13 This is a different matter from the opportunities opened up in trade between the Caribbean Basin countries and China, which will be analysed in another study.
} 
TABLE 5

United States: Structure of imports from the People's Republic of China and the Caribbean Basin, by Harmonized System sections, ${ }^{a} 1998$

(Millions of dollars and percentages)

\begin{tabular}{|c|c|c|c|c|c|}
\hline & & China & Percentage & Caribbean Basin & Percentage \\
\hline XI. & Textiles and textile articles & 7114.9 & 10.1 & 8390.9 & 50.2 \\
\hline II. & Vegetable products & 295.3 & 0.4 & 1828.0 & 10.9 \\
\hline V. & Mineral products & 696.8 & 1.0 & 1291.0 & 7.7 \\
\hline XVI. & $\begin{array}{l}\text { Machinery and mechanical appliances, electrical } \\
\text { equipment and parts thereof }\end{array}$ & 20385.0 & 29.0 & 1159.5 & 6.9 \\
\hline IV. & Prepared foodstuffs, beverages, tobacco & 299.7 & 0.4 & 1052.4 & 6.3 \\
\hline I. & Live animals and animal products & 451.7 & 0.6 & 605.4 & 3.6 \\
\hline VI. & Products of the chemical or allied industries & 1453.9 & 2.1 & 535.9 & 3.2 \\
\hline XVIII. & $\begin{array}{l}\text { Optical, photographic and musical instruments } \\
\text { and apparatus }\end{array}$ & 2991.7 & 4.3 & 420.8 & 2.5 \\
\hline XII. & Footwear, headgear, artificial flowers & 9230.4 & 13.1 & 378.7 & 2.3 \\
\hline XIV. & Natural or cultured pearls, precious metals & 399.5 & 0.6 & 315.4 & 1.9 \\
\hline \multicolumn{2}{|c|}{ Subtotal } & 43318.9 & 61.6 & 15978.0 & 95.6 \\
\hline \multicolumn{2}{|l|}{ Others } & 27061.0 & 38.4 & 16722.0 & 4.4 \\
\hline \multicolumn{2}{|l|}{ Total } & 70379.9 & 100 & 11940.6 & 100.0 \\
\hline
\end{tabular}

Source: The authors, on the basis of data from the United States Department of Commerce, MAGIC.

a The Harmonized System is divided into 21 sections.

countries in the Basin the figure was less than $0.7 \%$. Each of these sectors will now be analysed separately.

\section{Wearing apparel}

China is one of the largest suppliers of wearing apparel to the United States. As table 6 shows, however, its market share in these products fell between 1990 and 1998 from $13.9 \%$ to $11.4 \%$. This was largely due to the existence of restrictive quotas that limit increases in the supply of these goods to the United States market. Many Chinese export products are subject to individual quotas, which has reduced their annual growth to $0.2 \%$ or $0.5 \%$ (USITC, 1999a). ${ }^{14}$

\section{a) Market share}

In February 1997, the United States concluded new agreements with China in relation to the trade in textile products and wearing apparel. One of them extended

\footnotetext{
${ }^{14}$ Contrary to what is generally believed, the cost of sea transport is not significant as a differential (Gitli and Arce, 2000a), but delivery times, the distance that has to be covered when specific problems need to be solved and the cost of air transportation may be far more important factors working against China.
}

the life of United States quotas for Chinese non-silk goods for four years, until the end of 2000. This cut quotas for those products in respect of which China has constantly breached the limits by smuggling them through third countries (especially Hong Kong and Singapore), taking advantage of their unused quotas. At the same time, the rules against this type of trade were tightened (box 2).

The Caribbean Basin countries, meanwhile, increased their share of the United States market in the 1990s at the expense of the Asian countries that are subject to quotas, among which China is very important. Since 1994, Mexico has made use of the tariff advantages granted by the United States under the North American Free Trade Agreement (NAFTA) to increase its exports of wearing apparel to the United States. It is a fact that Mexico is the country that has increased its exports of these goods most quickly, so that it has taken most of the market share lost by the Asian countries; in 1998, the Caribbean Basin as a whole saw a decline in its market share, which had shown a rising trend over the decade. The increase in Mexico's market share since 1995 has also been influenced by the devaluation of that country's currency in late 1994, which further enhanced the advantages accruing to it from NAFTA (Gitli and Arce, 2000a). 
TABLE 6

Selected countries: Share of United States wearing apparel imports, 1990-1999

\begin{tabular}{lrrrrrrrrrrrr}
\hline & 1990 & 1991 & 1992 & 1993 & 1994 & 1995 & 1996 & 1997 & 1998 & 1999 \\
\hline \multirow{2}{*}{ China } & 13.9 & 14.5 & 15.8 & 17.4 & 15.3 & 12.9 & 13.2 & 13.4 & 11.4 & 11.1 \\
Caribbean Basin & 8.4 & 10.4 & 11.3 & 12.9 & 13.1 & 14.7 & 15.5 & 16.8 & 16.4 & 16.5 & \\
Mexico & 2.8 & 3.5 & 3.9 & 4.3 & 5.3 & 7.4 & 9.6 & 11.4 & 13.1 & 14.3 \\
\hline
\end{tabular}

Source: The authors, on the basis of data from the United States Department of Commerce. Wearing apparel products are those listed under codes 61 and 62 of the Harmonized System.

Box 2

The China-European Union Agreement

On 19 May 2000, China and the European Union reached bilateral agreement on the tariff preferences that the former is to grant to the latter, with the objective of giving the European Union access to China. The following are some of the main provisions of this agreement.

For the 150 priority products of the European countries, the average tariff will be cut from $18.6 \%$ to $10.6 \%$.

Tariffs for five footwear products accounting for over $70 \%$ of European Union exports in this category will be cut from $25 \%$ to $10 \%$.

For 52 products related to the "machinery and applications" sector that account for $26 \%$ of all European exports, tariffs will be cut to between $5 \%$ and $10 \%$ from the levels of over $35 \%$ currently applied.

Some of the concessions obtained by the European Union in respect of agricultural products were:

\begin{tabular}{lcc} 
Product & Current tariff & Tariff agreed on \\
\hline Butter & $30 \%$ & $10 \%$ \\
Powdered milk & $25 \%$ & $10 \%$ \\
Pasta & $25 \%$ & $15 \%$ \\
Wine & $65 \%$ & $14 \%$ \\
Mandarins & $40 \%$ & $12 \%$
\end{tabular}

As in the case of the United States, China undertook to sign the agreement on sanitary and phytosanitary measures in the framework of WTO.

As regards telecommunications, foreign operators can own $25 \%$ of the total. This level will rise to $35 \%$ and $49 \%$ in the first and third years after the agreement comes into effect. In the field of insurance, seven new licences to provide this service were granted to European companies. Retail distribution businesses will no longer be subject to the 50-50 strategic alliance restriction, nor will they be limited to a maximum size of 20,000 square metres or no more than 30 outlets.

Source: European Union (2000).

A substantial proportion of Caribbean Basin products enter the United States on a special production sharing basis. In the garment sector, the countries of the Basin account for $83.7 \%$ of everything imported under this system (table 7). Of the total coming in on a production sharing basis, $63.9 \%$ by value is made from content of United States origin, so that the countries of the Basin do not pay tariffs on this percentage. ${ }^{15}$

${ }^{15}$ For the garment sector, entry on a production sharing basis means that the cloth has been cut in the United States and sent to the Basin for sewing, with customs duties payable only on the value added abroad. By contrast, China pays the tariff on the entire
There is a large difference between the United States component used by the Latin American countries and that used by all the others. In the case of the former the proportion is $43.2 \%$ at the lowest (in Guatemala), while elsewhere it is just $16.5 \%$. This reflects the fact that countries further away from the United States, like the Asian ones, do not have much incentive to make clothing under the production sharing system, owing

product. It is not very clear how much of an advantage this now represents for the countries of the Basin, as not only is Chinese labour cheaper, but cloth is as well. 
TABLE 7

United States: Imports of wearing apparel entering on a production sharing basis, and United States content of these, 1997

(Millions of dollars and percentages)

\begin{tabular}{|c|c|c|c|c|c|}
\hline & Total & $\begin{array}{l}\text { Production } \\
\text { sharing }\end{array}$ & $\begin{array}{l}\text { Percentage } \\
\text { of total }\end{array}$ & $\begin{array}{l}\text { United States } \\
\text { content }\end{array}$ & $\begin{array}{l}\text { Production sharing } \\
\text { percentage }\end{array}$ \\
\hline Mexico & 6586 & 5187 & 78.8 & 3368 & 64.9 \\
\hline Dominican Republic & 2349 & 2154 & 91.7 & 1358 & 63.0 \\
\hline Honduras & 1875 & 1586 & 84.6 & 1130 & 71.2 \\
\hline El Salvador & 1170 & 1006 & 86.0 & 580 & 57.7 \\
\hline Costa Rica & 827 & 791 & 95.7 & 524 & 66.2 \\
\hline Jamaica & 422 & 382 & 90.5 & 309 & 80.9 \\
\hline Guatemala & 1150 & 706 & 61.4 & 305 & 43.2 \\
\hline Haiti & 225 & 211 & 93.8 & 155 & 73.5 \\
\hline Colombia & 364 & 253 & 69.5 & 148 & 58.5 \\
\hline Nicaragua & 232 & 67 & 29.9 & 47 & 70.1 \\
\hline Others & 38374 & 599 & 1.6 & 99 & 16.5 \\
\hline Total & 53574 & 12939 & 24.2 & 8024 & 62.0 \\
\hline Caribbean Basin & 8307 & 6949 & 83.7 & 4438 & 63.9 \\
\hline
\end{tabular}

Source: USITC (1999b).

TABLE 8

Countries supplying wearing apparel: Possible losses and gains in United States market share owing to China's wTO entry and the abolition of quotas

\begin{tabular}{lll}
\hline & World market & United States \\
\hline China & Increase of over 6\% & Increase of some 3\% \\
Mexico and Canada & Small reduction & Loss of 2\% \\
All others ${ }^{\mathrm{a}}$ & Loss of some 3\% & Loss of some 4\% \\
\hline
\end{tabular}

Source: USITC (1999b).

a The "all others" category includes the countries of the Caribbean Basin, Brazil, the European Union countries and other small suppliers. The United States International Trade Commission (USITC) study does not isolate the impact on the Basin countries in any instance, so these figures are authors' estimates.

to the difficulties that would be involved in moving cloth and other United States inputs from the United States to begin producing the goods.

If China joined WTO, abolition of the quotas currently applied under the Agreement on Textiles and Clothing, which would happen in 2005, would enable the country to increase its world market share substantially, and this would greatly affect other regional suppliers of these goods. In fact, according to United States government estimates, if these quotas were done away with China could raise its world market share by more than six percentage points in 2005; this would help the country to maintain its position as the world's leading supplier of garment products, and then stabilize this share at about 37\% (USITC, 1999b).

Where the United States market is concerned, China's wTO entry and the abolition of quotas would have considerable effects on the composition of countries supplying the United States with its imports of wearing apparel (table 8). For these products, China's market share could be expected to increase by three percentage points in 2005, with the abolition of quantitative restrictions. The countries of South Asia ${ }^{16}$ would also benefit from the removal of these quotas: their share would rise by approximately four percentage points in 2005 or thereabouts and would continue to follow a rising trend in subsequent years. The increase in market share for China and the South Asian countries would mean a fall of some four percentage points in the market share of "all others", among which the countries of the Caribbean Basin would undoubtedly be hard hit. ${ }^{17}$

Again, by virtue of the Trade and Development Act passed in the United States in 2000, the countries of the Caribbean Basin now enjoy broader tariff preferences than they had under the Caribbean Basin Initiative (CBI). We believe that this law, which came into force on 1 October 2000, will undoubtedly give a

\footnotetext{
${ }^{16}$ Bangladesh, India, Nepal, Pakistan and Sri Lanka.

${ }^{17}$ Although the United States, as was seen in section IV, reserves the right to apply textile safeguards until 2008, which casts rather more uncertainty over the intervening period.
} 
new impetus to production in the countries of the Basin and mitigate the effect that abolition of the quotas for Chinese goods will have on them. Thus, of the "all others" group, the Basin will be the only subregion that will not be adversely affected. ${ }^{18}$

The United States Government also expects a small decline in Mexico's market share from 2005 onward, owing to the abolition of quotas for wearing apparel. That country should be less affected, however, owing to the preferences it enjoys under NAFTA.

\section{b) Relative prices and competition}

We shall now look at the relative prices of Chinese supplies to the United States market by comparison with the prices of goods from the Caribbean Basin. To do this, we shall take the three main apparel products exported by the countries of the Basin to the United States in 1998: men's trousers and breeches, men's Tshirts and men's cotton shirts. ${ }^{19}$ As can be seen from table 9, China is supplying the United States market with these products at prices quite similar to those of the Basin countries, so it seems that, in this instance at least, it is not competing on price. This could indicate that the main differentiation factor following Chinese entry into WTO would be the removal of quotas.

Today, however, China is not just one of the world's largest suppliers of low-priced clothing, but is also becoming a low-cost producer of high-quality, highvalue garments, something that may be due to the imposition of quotas by the United States to prevent imports of low-quality products. This shift towards higher-value products is reflected in the way production of goods of this type is being switched from Hong Kong to China, as a result of which the number of employees in the Hong Kong garment industry fell from 128,000 to 45,000 between 1993 and 1998 (USITC, 1999b, section 8, p. 6).

In passing legislation to extend preferences for the countries of the Caribbean Basin, what the United States is promoting is its own domestic production. This is because activity in the Basin is very much centred on the production sharing system, whereby $64 \%$ of all clothing exported by these countries is made from United States content. Consequently, the legislation

${ }^{18}$ See the footnote to table 8 for a definition of "all others".

${ }^{19}$ These products account for $3.7 \%, 2.6 \%$ and $2.4 \%$, respectively, of all United States imports from the Caribbean Basin countries and come under tariff classifications 6203424015, 6109100012 and 6105100010 of the Harmonized System.
TABLE 9

Selected Caribbean Basin and other countries: Relative prices of the main apparel products imported from them by the United States ${ }^{a-b}$

(Average 1995-1998)

\begin{tabular}{lrrr}
\hline Country & $\begin{array}{c}\text { Men's } \\
\text { trousers }\end{array}$ & $\begin{array}{c}\text { Men's } \\
\text { T-shirts }\end{array}$ & $\begin{array}{c}\text { Men's } \\
\text { cotton shirts }\end{array}$ \\
\hline China & 0.97 & 1.00 & 1.42 \\
Costa Rica & 0.95 & - & - \\
El Salvador & - & 0.78 & 0.64 \\
Guatemala & - & - & 0.81 \\
Hong Kong & 1.14 & 2.85 & 1.70 \\
Honduras & 1.00 & 0.88 & 0.77 \\
Jamaica & - & 0.91 & - \\
Mexico & 0.98 & 1.01 & 0.77 \\
Dominican Rep. & 1.00 & 0.80 & 0.86 \\
\hline
\end{tabular}

Source: United States Department of Commerce, MAGIC.

a The fact that no data on particular products are given for certain Caribbean Basin countries does not mean that these countries do not export them, but only that they are not among the region's top three suppliers of them.

b United States imports from Hong Kong are very likely to have originated in China, so these figures should be treated with caution.

passed will increase the use of United States yarn and cloth in the countries of the Basin, so that future growth in the textile and clothing industries of those countries will enable the United States to counter the adverse developments seen in its domestic textile industry, where employment fell from 675,000 to 596,000 people between 1993 and 1998 (USITC, 1999b, section 8, p. 2). The production linkages deriving from intensive utilization of United States raw materials are considerable, so a rise in the market share of the Basin would benefit the United States textile industry.

The web of conflicts of interest among textile producers, garment producers and distributors is extremely difficult to untangle. Figure 2 summarizes the structure and interrelationships of these groups, and their sometimes contradictory approaches. Distributors tend to require "complete packages" (Arias, 1999; Zúñiga, 1999 and Gereffi, 2000). Such being the case, distributors (who often also produce clothing under subcontracting arrangements) will not be too interested in the provenance of the cloth, but only in its quality and specifications. Consequently, they will be ready to enter into negotiations with anyone (China, CBI, etc.). By contrast, United States textile producers are interested in expanding the scope and benefits of production sharing as a way of increasing the market for their cloth. 
The United States Trade and Development Act of 2000 extended the tariff preferences enjoyed by the countries of the Caribbean Basin as part of the 1984 Caribbean Basin Initiative.

For footwear, ${ }^{a}$ tuna, petroleum and its derivatives, clocks and "flat" leather products such as wallets ${ }^{\mathrm{b}}$ the tariff will be the same as for Mexico, provided the North American Free Trade Agreement rules of origin are complied with.

Textile and clothing products remain subject to a special regime, whereby the following may enter free of quotas and tariffs: ${ }^{c}$

1. Wearing apparel manufactured from United States cloth and yarn and cut in the United States (production sharing or maquila), a range of additional washing and processing operations being permitted for these products. It is also permissible for United States cloth to be cut in the region, although in these cases it would appear that processes subsequent to assembly are not allowed.

2. Certain products knitted in a beneficiary country from yarn produced in the United States (with the exception of tights as listed in item 6115 of the Harmonized System) and wearing apparel knitted, cut and completely assembled in one or more beneficiary countries from cloth produced in the region using United States yarn. This concession is subject to an initial yearly limit of 250 million square metres equivalent of cloth, an amount that will increase by $16 \%$ a year until 2004, when growth in the quota will be set by law. In this case, it would appear that processes subsequent to manufacture are not allowed, as this option is not clearly provided for in the legislation.

3. Cotton T-shirts, knitted or crocheted, except underwear (61091000 in the Harmonized System) and T-shirts, knitted or crocheted, of other textile materials (61099010), made in one or more beneficiary countries from cloth produced in one or more countries of the region, using yarn made in the United States. For this case, a ceiling of 4.2 million dozens of T-shirts made from cloth complying with the rules of origin applies, this limit to rise by $16 \%$ a year until 2004, when the growth rate will be set by law.

4. Any apparel product classified under subitem 621210 (brassieres), if the article is cut and sewn, or assembled, in the United States or any of the beneficiary countries. These products will be eligible for preferential treatment if they contain at least $75 \%$ United States cloth.

5. Products assembled from fibres, yarn or cloth not available in commercial quantities in the region (NAFTA countries). Hand-made products, craft products and textile luggage.

Lastly, particularly sensitive agricultural products, such as sugar, ${ }^{\mathrm{d}}$ beef, frozen juices, tobacco and jewellery boxes, which were subject to quotas and subsequently to tariffs, are unaffected by the new legislation. For these, then, there is no parity with NAFTA.

Source: Gitli and Arce (2000b).

a Maquila footwear had entered tariff-free since 1990.

${ }^{b}$ Flat products had been subject to reduced tariffs since 1990 .

c In certain cases, such as those noted in points 2 and 3, products are subject to quotas.

d Access to the sugar market for the CBI countries is subject to quotas but free of tax.

On this point, Gereffi (2000) analysed the way the garment sector in the United States had been restructured and reached the conclusion that established producers in both Mexico and Asia are aiming to produce the "complete package". In the case of Mexico, this tendency is accounted for by the opportunities for production integration offered by NAFTA, while in the case of Asia it would appear to be due to the strong linkages that exist among Asian producers. $\mathrm{Ng}$ and Yeats (1999) have found that the trade in components and inputs among the Asian countries is much greater than might have been thought. For example, of all imports of products of this type by these countries in 1996, $58.5 \%$ were from within the region, which gives an idea of the importance of the "production sharing" that appears to be going on among Asian countries. ${ }^{20}$
China has every opportunity to compete in the international market for wearing apparel, thanks to its low wage costs. Wages there are just $17 \%$ of those in Costa Rica, $28.5 \%$ of those in Mexico and $33.6 \%$ of those in Guatemala, which means that the final prices of the country's products can be considerably lower than those offered by the countries of the Basin (table 10).

Of the garment companies located in China, in 1995 some $42 \%$ were foreign-owned, almost $40 \%$ were township enterprises, $7 \%$ were private-sector companies

\footnotetext{
${ }^{20}$ Here we are considering "production sharing" not as a customs classification, but as a division of labour whereby each country carries out different stages of the production process, according to the labour and know-how it has available.
} 
FIGURE 2

Textile-clothing chain: Production and sales flows, and views on China and on NAFTA parity for the CBI countries
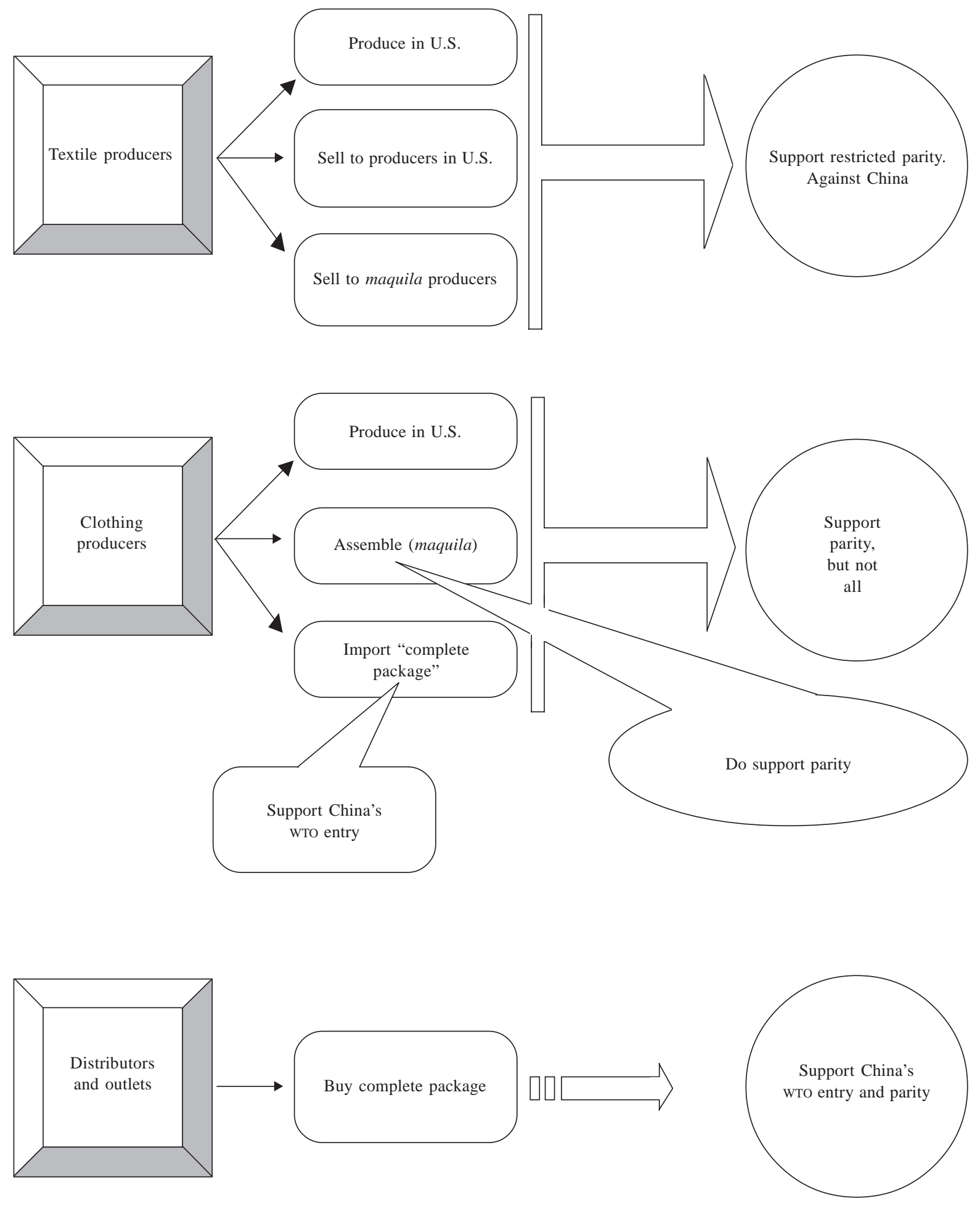
TABLE 10 Selected countries: Labour costs in the apparel industry ${ }^{\mathrm{a}}$ (Dollars per hour)

\begin{tabular}{lrr}
\hline & 1996 & 1998 \\
\hline United States & 9.56 & 10.12 \\
Hong Kong & 4.51 & 5.20 \\
South Korea & 4.18 & 2.69 \\
Costa Rica & 2.38 & 2.52 \\
Dominican Republic & - & 1.49 \\
Mexico & 1.08 & 1.51 \\
Guatemala & 1.31 & 1.28 \\
Honduras & - & 1.05 \\
China & 0.28 & 0.43 \\
India & 0.36 & 0.39 \\
Bangladesh & 0.31 & 0.30 \\
Indonesia & 0.34 & 0.16 \\
\hline
\end{tabular}

Source: USITC (1999b, section 8, p. 7) for 1996 and 1998 data, and Gitli (1997) for data on the Dominican Republic and Honduras, which relate to 1997 .

a Labour costs include social charges.

and just 6\% were State-owned. Export production depends heavily on cloth imported from Hong Kong, Italy, Japan, the Republic of Korea and Taiwan, among others, some $55 \%$ of wearing apparel being made from imported cloth (USITC, 1999b, section 8, p. 5).

As we have seen, the combination of China's possible WTO entry and the opening up of quotas for textile products in 2005 threatens to unleash a major crisis for the countries of the Caribbean Basin, which need to address this challenge seriously. Decisions on investments to enhance their competitive advantages need to be taken within this time horizon.

\section{Footwear}

Footwear (Harmonized System code 64) could be another type of product for which China might pose an increased competitive threat to the countries of the Caribbean Basin. As we saw earlier in table 5, 13.1\% of United States imports from China are "footwear, headgear and artificial flowers", the third largest category in the trade between the two countries. In the Caribbean Basin, as was mentioned earlier, footwear is produced overwhelmingly by the Dominican Republic, so the ensuing analysis will focus exclusively on that country.

It should be explained here that footwear is: i) excluded from the tariff preferences of the Generalized System of Preferences, ii) semi-excluded from CBI (if a country in the Basin makes footwear under the production sharing system, this product will be free of taxes when it enters the United States) and iii) included in CBI since the new act of 2000.

Of the Dominican Republic's footwear exports, $34.2 \%$ are produced under the production sharing system. Of this proportion, $66.5 \%$ is made with United States content and thus benefits from partially tax-free entry to the United States. In this respect it has an advantage over China, a country which could indeed take advantage of the benefits of production sharing, but does not do so because of the linkages that characterize the production structure in East Asia, which mean that inputs are supplied from within the region.

We shall now look at two of the main export products of the Dominican Republic, to see whether or not there is competition from China and, if so, under what price conditions. To this end, we shall analyse the first- and second-ranking products in the footwear category of the Dominican Republic's export trade with the United States: i) parts of footwear, other uppers and parts thereof other than stiffeners of leather (6406106500) and ii) footwear with outer soles rubber/ plastic or natural or regenerated leather (not for sports) and textile uppers (6404193515).

The first product -“parts of footwear, other uppers and parts thereof other than stiffeners of leather"accounts for some 4\% of the Dominican Republic's total exports to the United States, and thus is a very important part of the country's export structure, with a share in the United States market that rose from $47.3 \%$ to $60.5 \%$ between 1990 and 1998, although it peaked in 1994 at $63.3 \%$ and then began to decline slightly. Mexico has increased its share of the same market, especially since 1995, which could be due to the incentives to invest there resulting from NAFTA and, to some extent, the Mexican devaluation of late $1994 .^{21}$ China also increased its United States market share considerably between 1990 and 1998, from $0.5 \%$ to $7.7 \%$, but this share peaked in 1995 at $10 \%$ and then began to decline.

If we analyse the relative pricing structures of each of the main countries supplying this product, ${ }^{22}$ we find the following. The Dominican Republic supplies this product at prices $27 \%$ higher than the average for all the suppliers, while Mexican prices are 4\% lower than this average. China sells at prices that are much lower

\footnotetext{
21 In addition, United States inputs account for $8 \%$ by value of footwear imports from Mexico (USITC, 1999c).

22 By relative prices are meant the price of imports from each country in relation to the average price of imports from all the countries.
} 
even than those of Mexico, and 54\% below the average for all the suppliers (table 11).

Let us now look at the second-placed export product of the Dominican Republic. This is "footwear with outer soles rubber/plastic or natural or regenerated leather (not for sports) and textile uppers", and represents $0.5 \%$ of the Dominican Republic's total exports to the United States. The Dominican Republic increased its market share considerably between 1990 and 1998 , from $0 \%$ to $37.1 \%$. Its main competitor, China, raised its share from $14.2 \%$ in 1990 to $35.5 \%$ in 1998. Mexico, which in 1990 was the main supplier with $82 \%$, saw its share fall right down to $18 \%$ of the total in 1998.

A look at relative prices shows that the same situation obtains here as with the previous product: the relative prices of the Dominican Republic's supplies were above the average (approximately $60 \%$ higher in 1996-1998 and 100\% in 1995-1998), while those of China were $28 \%$ lower in 1995-1998.

Given this situation, if the agreement signed encourages the United States to import this product from China, that country will be able to compete in the United States market at prices much lower than those of the Caribbean Basin countries and Mexico, whose competitiveness in that market could be affected. This would come about because China would be guaranteed the most favoured nation tariff, which is almost as important as a tariff reduction, since it would lend stability to the trade with that country.

\section{Other instruments used in medical, surgical, dental or veterinary sciences ${ }^{23}$}

Ranking fourth among the products imported by the United States from the Caribbean Basin is the category of "other instruments used in medical, surgical, dental or veterinary sciences". This category accounted for $2.8 \%$ of all United States imports from the Basin in 1998, the main suppliers being the Dominican Republic and Costa Rica, with market shares of $30.3 \%$ and $5.5 \%$, respectively. Mexico also accounted for almost $30 \%$ of
TABLE 11

Selected Caribbean Basin and other countries: Relative prices of the main footwear products imported from them by the United States ${ }^{a}$

(Average 1995-1998)

\begin{tabular}{lcc}
\hline & $\begin{array}{c}\text { Parts, other uppers } \\
\text { and parts thereof }\end{array}$ & $\begin{array}{c}\text { Footwear } \\
\text { (not for sports) }\end{array}$ \\
\hline Dominican Republic & 1.27 & 2.01 \\
China & 0.46 & 0.72 \\
Mexico & 0.96 & 0.92 \\
Canada & - & 1.54 \\
Honduras & 0.95 & - \\
India & 1.05 & - \\
Costa Rica & 1.59 & - \\
Argentina & 1.49 & - \\
\hline
\end{tabular}

Source: United States Department of Commerce, MAGIC.

a Where relative product prices are not given for a particular country, this may mean not that it does not sell the product, but that it is not a major competitor for this product in United States imports.

this trade. China supplied just $0.2 \%$ of United States imports of these products, so that it does not seem to be a major competitor for the countries of the Basin.

\section{Parts and accessories of automatic data processing machines ${ }^{24}$}

This product ranks sixth among United States imports from the countries of the Caribbean Basin, accounting in 1998 for $2.6 \%$ of total imports from those countries. The country in the Basin that has been supplying it is Costa Rica, since Intel set up there in 1997; the country's market share the next year was $2.2 \%$. Mexico also sells products in this category to the United States, accounting for $7.9 \%$ of all United States purchases of this type in 1998. That same year, China had a 5\% market share in the United States, thereby showing itself to be a strong competitor to Costa Rica and Mexico. In this case, however, the monopolization of the world market is mitigating the problem for Costa Rica.
${ }^{23}$ This product is classified as 9018908000 in the Harmonized System.

\footnotetext{
${ }^{24}$ This product is classified as 8473301000 in the Harmonized System.
} 


\section{VI}

\section{Conclusions}

The entry of China into wTO will lead to major changes in the reciprocal trading relationship between that country and the United States, but it will also affect the way the two countries' trade with other trading partners develops.

One of the largest increases in Chinese exports to the United States could occur in the textiles and clothing sector. This trade has hitherto been restricted by the use of quotas, but from 2005 onward China could increasingly be a supplier of cheaper products to the United States market, which would not only prejudice the United States textile and clothing industry, but would increase the competition facing the countries of the Caribbean Basin and Mexico, currently major suppliers of apparel products. In fact, the United States Government expects China to increase its share of the United States market for these products by some three percentage points.

This could cause serious problems for the economies of the Basin, which have already seen the growth rates of their textile exports decline because of NAFTA and the Mexican devaluation of December 1994. Nonetheless, the recently passed legislation extending the tariff preferences enjoyed by the Caribbean Basin under $\mathrm{CBI}$ is producing a twofold change in the ground rules by favouring the countries of the Basin, and will mean problems for other exporters of wearing apparel.

The important thing where this sector is concerned is that, whether or not China enters WTO, the abolition of quotas in the United States market for apparel products is inevitable. The greatest winners look like being the countries of South Asia, and the main losers those of the Caribbean Basin and, to a lesser extent, Mexico. The entry of China into wTO would exacerbate yet further the situation described, as it would give the country greater access to the United States market and thus restrict yet further the growth opportunities of the countries in the Basin. As was pointed out earlier, however, these have been boosted recently by the expansion of trade benefits.

To sum up, the countries of the Basin have a window of opportunity between 2000 and 2005 in which to restructure their textile and garment sector so that they can take the initiative. This has implications that cannot be gone into here, but it suggests that consideration should be given to the need to organize support policies for the sector and the very basis on which investment is sought.

In the footwear industry, China is a strong competitor to the Dominican Republic, and is in a position to sell more cheaply, as it has been doing hitherto. Consequently, strong trading relations between the United States and China could have adverse implications for the future of imports of this type from the Dominican Republic.

In the "other medical instruments" category, China is a major competitor to the exports of the Dominican Republic and Costa Rica to the United States, so close attention should be paid to China's options for increasing its exports in this area. As regards "parts of data processing machines", China does not seem to be a major competitor to Costa Rica, as it supplies just $0.2 \%$ of the United States market.

From the above it follows that the sectors in the Caribbean Basin that could be most affected by the entry of China into wTO are wearing apparel and footwear.

Lastly, the countries of the Basin -and of the rest of the American continent- should see the extension of CBI preferences as the first practical positive sign sent out by the United States regarding the prospects of its negotiating the Free Trade Area of the Americas. In the particular case of the Basin countries, the legislation states that the President of the United States should take all measures necessary to set a timetable of meetings between trade ministers from the countries of the Basin and the Trade Representative of the United States, in order to reach an agreement between the United States and the CBI countries that is advantageous for both parties and contains provisions similar to those of NAFTA. This means that the door is open for the countries of the Basin to begin negotiations with the United States Government on an agreement that will make parity with NAFTA a reality. 


\section{Bibliography}

Arias, C. (1999): Guatemala busca alternativas competitivas, Georgia, Apparel Industry International/Bill Communications, September-October.

Bates, G. (1999): Limited engagement, Foreign Affairs, vol. 78, No. 4, New York, Council on Foreign Affairs.

Bosworth, P. and G. Ofer (1995): Reforming planned economies, An Integrating World Economy, Washington, D.C., The Brookings Institution.

Chacón, F. (2000): International trade in textiles and garments: Global restructuring of the sources of supply in the United States in the 1990s, Integration and Trade, vol. 4, No. 11, Washington, D.C., Inter-American Development Bank (IDB).

Economy, E. (1999): Painting China green, Foreign Affairs, vol. 78, No. 2, New York, Council on Foreign Affairs.

Elliot, R. (2000): Argentina Sees Fatter Farm Exports with China Pact, Reuters, 22 March.

EU (European Union) (2000): The Sino-EU agreement on China's accession to the WTO: Results of the bilateral negotiations, Brussels, May, www.europa.eu.int.

GAO (General Accounting Office) (2000): World Trade Organization. China's Membership Status and Normal Trade Relations Issues, Washington, D.C.

Gereffi, G. (2000): The transformation of the North American apparel industry: Is NAFTA a curse or a blessing?, Integration and Trade, vol. 4, No. 11, Washington, D.C., IDB.

Gitli, E. (1997): La industria de la maquila en Centroamérica, San José, Costa Rica, International Labour Organization (ILO), December.

Gitli, E. and R. Arce (2000a): The imbalances of the Caribbean Basin countries with respect to NAFTA: The garment industry, Integration and Trade, vol. 4, No. 11, Washington, D.C., IDB. (2000b): ¿Qué significa para la cuenca del Caribe la ampliación de preferencias comerciales de EE.UU.?, Capítulos, No. 59, Caracas, Latin American Economic System (SELA).

IMF (International Monetary Fund) (2000a): Balance of Payment Statistics, Washington, D.C.

(2000b): International Financial Statistics, Washington, D.C.

Lardy, N. (2000): Permanent Normal Trade Relations for China, Policy Brief No. 58, Washington, D.C., The Brookings Institution, May.

Lin, J.Y., F. Cai and Z. Li (1998): Competition, policy burdens, and state-owned enterprise reform, The American Economic Review, vol. 88, No. 2, Nashville, Tennessee, American Economic Association.

Ministry of Foreign Trade (2000): Proceso de adhesión de China a la OMC: estado a mayo de 2000, San José, Costa Rica, Foreign Trade Office.
Mody, A. and F. Wang (1997): Explaining industrial growth in coastal China: Economic reforms... and what else?, The World Bank Economic Review, vol. 11, No. 2, Washington, D.C., World Bank.

Ng, F. and A. Yeats (1999): Production Sharing in East Asia: Who Does What for Whom and Why?, Washington, D.C., World Bank, Trade Team, Development Research Group.

Public Citizen (1999): Clarifying the rules on wTo accession. China and MFN status, Washington, D.C., Public Citizen Global Trade Watch, 24 May, http://www.citizen.org.

The Economist (1997): A survey of China: Ready to face the world?, London, The Economist Newspaper Limited, March.

The Journal of Commerce (2000a): China should listen, The Journal of Commerce Online, 4 February, http://www.joc.com.

(2000b): Time runs down on China Pact, The Journal of Commerce Online, 18 February, http://www.joc.com.

(2000c): Clinton's biggest battle this year: trade, The Journal of Commerce Online, 23 February, http:// www.joc.com.

UNCTAD (United Nations Conference on Trade and Development) (1999): World Investment Report 1999: Foreign Direct Investment and the Challenge of Development, New York.

United Nations (1999): World Economic and Social Survey 1999. Trends and Policies in the World Economy, New York. United Nations publication, Sales No. E.99.II.C.1.

United States-China Business Council (2000): Copy of U.S.-China Bilateral Market Agreement as Released by USTR on March 14, 2000, Washington, D.C., http://www.uschina.org.

USITC (United States International Trade Commission) (1999a): Industry and Trade Summary: Apparel, Publication No. 3169, Washington, D.C., March.

(1999b): Assessment of the Economic Effects on the United States of China's Accession to the WTO, Investigation No. 332-403, Washington, D.C., September.

(1999c): Production Sharing: Use of U.S. Components and Materials in Foreign Assembly Operations, 1995-1998, Investigation No. 332-237, Washington, D.C., December.

White House (2000): Summary of U.S.-China Bilateral WTO Agreement, Washington, D.C., China Trade Relations Working Group, 2 February.

World Bank (1999): World Development Indicators, 1999, Washington, D.C.

WTO (World Trade Organization) (2000): China's accession to the WTO, www.wto.org/wto/about/china.html.

Zúñiga, C. (1999): El Salvador se enfoca en el paquete completo, Apparel Industry International, Georgia, Bill Communications, November-December. 